Military Technical College

Kobry El-Kobbah,

Cairo, Egypt $9^{\text {th }}$ International Conference

on Electrical Engineering

ICEENG 2014

WS104:

\title{
Green Communities
}

\author{
By
}

Magdy El-Sharkawy

\section{Abstract:}

Green growth for the deserts of the Arab establishment unstable or built-up on an area of 50000 acres in Western Sahara Valley area ocher which is characterized by the genius of the geographical location where it mediates the desert and have many of the roads leading to it from the provinces of Alexandria, Beheira, Giza, Cairo, Matrouh and New Valley, and the region by the diversity Biolojoa and geologist and is characterized by soil as valid and are ideal for the cultivation of clean, solar belts as falling throughout the year which leads her to produce and export energy as it is typical for the field of tourism environment because of the effects of fossils 50 million years ago. Also sources of the region's water naturally where there is water from the depths of 2 meters to 500 meters in the area surrounding the lake of an area of 400 acres, the project also features the establishment of villas and residential units per unstable or on neighboring thus achieving social justice in a society that includes rich and poor enjoy healthy eating and construction is compatible with environment and free of contaminants and diseases, and the safe processing of the waste. It also features a project to preserve the wealth of the natural environment and works to protect resources and the development and dissemination of culture through the establishment of institutes for Environmental Sciences and the protection of cultural heritage and human as the region has a long history and civilization, and each stable Ali integrated system solutions and solar energy in terms of irrigation, lighting, air conditioning, refrigeration and waste treatment. And support in the industry is also on the ecofriendly products are badly needed in the global market in various fields of agricultural, industrial and tourism, and that this project enables repeat create colonies adjacent stage first 50000 acres Bajmala investments ranging from 50 billion pounds and more, which is a pilot project attractive for investment is a mutation in a civilized Egypt in the field of growth Alakhcr where value is added through a stable global electronic smart and crowned the values and ideals that achieve the highest concepts of sustainable development and a global model for cities of the future.

- Chairman of the Arab Environment Association, Egypt 